\title{
FEDERAL HABEAS CORPUS REVIEW OF UNINTEN- TIONALLY DEFAULTED CONSTITUTIONAL CLAIMS
}

State prisoners whose federal constitutional claims have been rejected on the merits by state courts generally may seek federal court review by petitioning a federal district court for a writ of habeas corpus. ${ }^{1}$ An accused who fails to comply with state procedural requirements for raising federal constitutional claims may forfeit the right to raise the claim in the state courts. ${ }^{2}$ What effect such defaults should have on the availability of federal habeas review has been the subject of a line of Supreme Court cases.

In the 1963 landmark decision $F a y$ v. Noia, ${ }^{3}$ the Supreme Court held that procedural defaults of constitutional claims do not bar habeas review by federal courts. ${ }^{4}$ Having established the power

1 See Brown v. Allen, 344 U.S. 443 (1953). But see Stone v. Powell, 428 U.S. 465 (1976) (fourth amendment claims not cognizable on habeas unless state failed to provide a full and fair opportunity to raise them in the state court).

Federal habeas corpus review of state convictions is authorized by 28 U.S.C. $\$ 2254$ (1976).

For historical reviews of the "Great Writ," see Bator, Finality in Criminal Law and Federal Habeas Corpus for State Prisoners, 76 HARv. L. Rev. 441, 463-99 (1963); Reitz, Federal Habeas Corpus: Impact of an Abortive State Proceeding, 74 Harv. L. REv. 1315, 1324-32 (1961).

When unmodified, the term "habeas" in this Comment refers to federal habeas corpus proceedings.

2 For example, if state rules require a defendant to object to illegally seized evidence at or before the prosecution's attempt to introduce the evidence and if the state refuses to hear the objection unless it is raised in accordance with those rules, a defendant who fails to comply with the rule procedurally defaults the fourth amendment claim.

3372 U.S. 391 (1963).

The respondent, Noia, claimed a coerced confession had been used to convict him of murder, for which he was serving a life sentence. Noia failed to appeal his conviction in the state court, but after his co-defendants were successful on their appeals, Noia sought coram nobis review in the state court. His application was denied because he had not appealed earlier. On his habeas corpus petition, the federal district court held that Noia had failed to exhaust the available state remedies and therefore denied habeas review. The Supreme Court upheld the reversal by the Second Circuit, finding that Noia's failure to appeal, far from being deliberate, was a result of his "grisly choice" to avoid the possible imposition of the death penalty on appeal. Id. 440 .

4 Id. 428-29. State prisoners whose federal constitutional claims have been rejected by state courts generally may seek direct review of those claims by the United States Supreme Court by writ of certiorari. 28 U.S.C. $\$ 1257(3)$ (1976). Such review is not a matter of right; rather, it is discretionary, see Sup. CT. R. 17, and only rarely granted. But review by certiorari is never permitted when the prisoner's conviction is based on an "adequate and independent" state ground. See 
of the federal courts to entertain habeas petitions on procedurally defaulted claims, the Court went on to hold that procedural defaults would bar habeas review whenever the failure to comply with the state's procedural rule was a "deliberat[e] by-pass[]" of state procedures. ${ }^{5}$ A deliberate bypass would bar habeas review only when it was "the considered choice of the petitioner," " not when it was merely the considered choice of the petitioner's attorney. ${ }^{7}$

Fourteen years after Noia, the Court's decision in Wainwright v. Sykes ${ }^{8}$ marked the culmination of a line of cases ${ }^{9}$ casting doubt on the deliberate bypass standard.10 The Sykes Court held that Florida's "contemporaneous-objection rule" 11 barred habeas re-

Wainwright v. Sykes, 433 U.S. 72, 81; Fox Film Corp. v. Muller, 296 U.S. 207 (1935); Murdock v. Memphis, 87 U.S. (20 Wall.) 590 (1875). The prime example of a conviction resting on adequate and independent state grounds so as to bar direct Supreme Court review is one based on procedural defaults.

5372 U.S. at 438.

6372 U.S. at 439, quoting Johnson v. Zerbst, 304 U.S. 458, 464 (1938).

7 Whether such a bypass had occurred was to be judged according to the "classic definition of waiver," 372 U.S. at 439, "intentional relinquishment of a known right or privilege," id., quoting Johnson v. Zerbst, 304 U.S. at 464.

8433 U.S. 72 (1977).

9 In Kaufman v. United States, 394 U.S. 217 (1969), the Court held that the deliberate bypass standard enunciated in Noia also applied to habeas petitions filed by federal prisoners. The Court began to reverse the trend four years later in Davis v. United States, 411 U.S. 233 (1973). In Davis, the Court held that a federal prisoner could not raise on habeas a procedurally defaulted claim of unconstitutional discrimination in the composition of the indicting grand jury absent a showing of "cause" for failing to comply with the federal rule requiring such claims to be raised prior to trial. Id. 242. The Davis rule was extended to bar habeas review for state prisoners in another grand jury challenge, Francis v. Henderson, 425 U.S. 536 (1976). The Court held that the state's procedural rule barred habeas review unless the petitioner showed not only "cause" for the lack of timely objection, but also "actual prejudice" resulting from the failure to object. Id. 542 .

10 For a more complete look at the rise and fall of the deliberate bypass standard, see Hill, The Forfeiture of Constitutional Rights in Criminal Cases, 78 Colum. L. Rev. 1050 (1978); Rosenberg, Jettisoning Fay v. Noia: Procedural Defaults by Reasonably Incompetent Counsel, 62 MinN. L. Rev. 341 (1978); Tague, Federal Habeas Corpus and Ineffective Representation of Counsel: The Supreme Court Has Work to Do, 31 Stan. L. Rev. 1 (1978).

11 FLA. R. Crem. P. 3.190(i) required a pretrial motion to suppress an illegally obtained confession or admission, "but the court in its discretion may entertain the motion or an appropriate objection at the trial." Id., quoted in Sykes, 433 U.S. at 76 n.5. But see Rosenberg, supra note 10, at 406-07:

[D]esignating the procedure in question as a "contemporaneous-objection rule" is misleading. The decision whether to object to admission of a confession is not a split-second determination that counsel is required to make in the midst of trial by utilizing arcane knowledge possessed only by members of the legal profession. The Florida statute is typical of state criminal procedure rules that require motions to suppress confessions to be made prior to trial and permit the delaying of such objections until the 
view of a Miranda ${ }^{12}$ claim not presented to the state trial court unless the petitioner showed "cause" 13 for the failure to object and "prejudice" 14 resulting from the procedural default. Such a rule was required, the Court said, to prevent defense attorneys from "sandbagging" 15 -withholding constitutional claims at trial to ensure that a new trial could be obtained by resort to habeas in the event of conviction at the first trial. ${ }^{16}$ The Court further reasoned that the marshalling of "[s]ociety's resources" at trial was a "decisive and portentious event" that should not be diminished by the failure of federal habeas courts to honor contemporaneous-objection rules. ${ }^{17}$ This may be classified broadly as a concern for trial efficiency and finality. ${ }^{18}$

The Sykes majority chose not to define either "cause" or "prejudice"; instead, it held simply that the prisoner had failed to meet his burden on the issues and left their definition to a later date. ${ }^{19}$ The federal courts of appeals have devoted considerable effort to applying the Sykes test of cause and prejudice. ${ }^{20}$ Four years after the Sykes opinion, the courts have yet to resolve an important question: What showing is necessary for a state prisoner to satisfy the "cause" requirement for obtaining habeas review of a procedurally defaulted constitutional claim? ${ }^{21}$ This Comment takes the position that the "cause" requirement should be deemed satisfied whenever a default is unintentional. This test would dif-

trial only in exceptional circumstances. Therefore, the decision is one concerning which the attorney has ample opportunity to consult with his or her client.

Labeling the Florida procedure as a "contemporaneous-objection rule" is both a reflection of the majority's authoritarian view of the attorneyclient relationship and a means of rendering unnecessary an analysis of the client's interest in personal participation in the relinquishment of a constitutional right.

(Emphasis in original.)

12 See Miranda v. Arizona, 384 U.S. 436 (1967) (statements resulting from custodial interrogation inadmissible in absence of notice to accused of certain constitutional rights).

13433 U.S. at 87. note 5 .

14 Id. For development of the "cause and prejudice" standard, see supra

15433 U.S. at 89.

$16 \mathrm{Id}$.

17 Id. 90.

18 Id. 88.

10 Id. 87.

20 See infra note 51.

21 See infra notes $51-71$ and accompanying text. 
fer from the Noia deliberate bypass test by requiring the petitioner to prove that the default was unintentional, instead of forcing the state to prove that the default was deliberate. ${ }^{22}$ Use of an unintentional default standard should alleviate the Sykes majority's concern with sandbagging. Moreover, such a standard would encourage the states to develop procedures increasing trial efficiency and finality, procedures beyond those available to the federal courts. This Comment also urges adoption of the unintentional default standard to avoid automatically penalizing prisoners whose constitutional claims result from their attorneys' errors. Finally, the unintentional default standard is presented as a means to facilitate effective delivery of legal services.

Part I of this Comment explores the Court's opinion in Sykes and the ways that the courts of appeals have applied Sykes. Part II criticizes the Sykes Court's conception of why procedural defaults occur, poses an alternative analysis, and explores methods by which states can in fact control procedural defaults. Part III points to the difficulties in applying the Sykes bar to unintentionally defaulted claims and the disadvantages of circumventing that bar with a sixth amendment ineffectiveness-of-counsel claim. Part III summarizes by discussing the superiority of the unintentional default approach to the definition of "cause."

\section{Sykes EXAMINED}

\section{A. The Opinion}

The petitioner in Wainwright $v$. Sykes ${ }^{23}$ was represented by counsel who ran afoul of Florida's contemporaneous-objection rule by failing to raise a Miranda objection when the defendant's post-arrest statement was admitted into evidence. The lower federal courts found that the deliberate-bypass test did not bar his habeas petition. Justice Rehnquist's majority opinion, ${ }^{24}$ holding ha-

22 Noia had been interpreted as placing the burden of proof of deliberate bypass on the state. See United States v. LaVallee, 448 F.2d 671, 676 (2d Cir. 1971) (citing cases). See also Henry v. Mississippi, 379 U.S. 443, 452 (1965), citing Fay v. Noia, 372 U.S. at 438 . But see Bonaparte v. Smith, 448 F.2d 385, 386 (5th Cir. 1971). Because Noia does not explicitly declare where the burden rests, the question at least is open to either interpretation. For a discussion of the clear shift in burden under Sykes, see Tague, supra note 10, at 34-39.

23433 U.S. 72 ( 1977 ).

24 Chief Justice Burger and Justices Stewart, Powell, Blackmun and Stevens joined in Justice Rehnquist's majority opinion. Chief Justice Burger and Justice Stevens filed concurring opinions. Justice White concurred in the judgment and wrote separately. Justice Brennan, joined by Justice Marshall, dissented. 
beas review of Sykes' claims barred, limited what the Court termed the "dicta" ${ }^{25}$ of Fay $v$. Noia ${ }^{26}$ that permitted habeas petitioners, "absent a 'knowing waiver' or a 'deliberate bypass," "27 to violate state contemporaneous-objection rules and still obtain habeas review.

Discrediting the Noia approach, the Court expressed fear that Noia "may encourage 'sandbagging' on the part of defense lawyers, who may take their chances on a verdict of not guilty in a state trial court with the intent to raise their constitutional claims in a federal habeas court if their initial gamble does not pay off." 28 Such conduct defeats the aims of rules requiring contemporaneous objection: finality and orderly administration of state criminal procedure.

Contemporaneous-objection rules, the Court noted, further finality and orderly administration in various ways. Strict rules of procedural default ensure development of a factual record of the constitutional claim when the witnesses' recollections are freshest, ${ }^{29}$ allow the "judge who observed the demeanor of the witnesses to make the factual determinations necessary for properly deciding the constitutional question," ${ }^{30}$ and generally force the prosecution "to take a hard look at its hole card." 31 Underlying the Court's opinion was a sense that state courts are just as well equipped to process federal constitutional claims as are the federal courts. Thus, elimination of the Noia standard would make "the state trial on the merits the 'main event,' . . . rather than a 'tryout on the road' for what will later be the determinative federal habeas hearing." 32

The Sykes Court found that the petitioner had shown neither cause for failing to make the Miranda objection during the state trial nor resulting prejudice. ${ }^{33}$ But while holding that petitioner

25433 U.S. at 87.

26372 U.S. 391 (1963).

27433 U.S. at 85.

28 Id. 89.

29 Id. 88.

30 Id.

31 Id. 89.

32 Id. 90. But see Rosenberg, supra note 10, at 439 (Court's quest for finality an attempt "to squeeze the more refined and complex due process issues of the 1970's into a simplistic remedial mechanism that might have been adequate for the more elementary and readily recognizable due process claims presented in the first half of the twentieth century").

33433 U.S. at 91 . In holding that the standard had not been satisfied, the Court noted that the respondent had "advanced no explanation whatever for his failure to object at trial" and that the evidence of guilt other than the challenged 
Sykes would be denied habeas review, the Court declined to define precisely the "cause and prejudice" test. ${ }^{34}$ Justice Rehnquist simply described the standard as "narrower" 35 than the Fay v. Noia test; he also expressed confidence "that the rule will not prevent a federal habeas court from adjudicating for the first time the federal constitutional claim of a defendant who in the absence of such an adjudication will be the victim of a miscarriage of justice." 36

The "cause and prejudice" rule resulting from Sykes was a response to the concerns of finality and orderly administration and was in reaction to what the Court perceived to be the overly broad sweep of Noia. Under Noia, in the Court's view, not only could attorneys "sandbag," 37 but the "refusal of federal habeas courts to honor contemporaneous-objection rules may also [have made] state courts themselves less stringent in their enforcement [of orderly administrative rules]." 38

Chief Justice Burger and Justice Stevens concurred in the Court's opinion. ${ }^{39}$ Chief Justice Burger wrote separately to emphasize his view that Noia "was never designed for, and is inapplicable to, errors .... alleged to have been committed during trial." 40 The Chief Justice then distinguished between decisions made by the defendant and those that are left to counsel. Those decisions made by the defendant include "whether to plead guilty, waive a jury, or testify in one's own behalf"; ${ }^{41}$ the attorney's decisions are those involving the "day-to-day conduct of the defense." 42 The Fay v. Noia-Johnson v. Zerbst 43 "knowing and intelligent waiver

confession "was substantial to a degree that would negate any possibility of actual prejudice resulting to the respondent from the admission of his inculpatory statement." Id. (footnote omitted).

34 Id. 87.

35 Id.

36 Id. 91 .

37 Id. 89.

38 Id. The Court has acknowledged that trial participants may also believe "that there may be no need to adhere to those [constitutional] safeguards during the trial itself." Engle v. Isaac, 102 S. Ct. 1558, 1571 (1982).

39 See supra note 24.

40433 U.S. at 92 (Burger, C.J., concurring).

41 Id. 83 n.1, citing Standards Relating to the Prosecutron Function AND THE Defense Function $\$ 5.2$, at 237-38 (App. Draft 1971) [hereinafter cited as ABA STANDARDS].

42433 U.S. at 93 (Burger, C.J., concurring) (attorney has immediate and ultimate responsibility "of deciding if and when to object, which witnesses, if any, to call, and what defenses to develop.").

43304 U.S. 458, 464 (1938). 
standard," 44 the Chief Justice argued, is inappropriate for trial decisions resting solely with the defense attorney. ${ }^{45}$ Presumably, therefore, the "core holding" ${ }^{48}$ of Noia would continue to be viable only for those few decisions that are left to the accused. Justice Stevens added that the "cause and prejudice" standard seemed consistent with what the lower federal courts already had been doing. ${ }^{47}$

Agreeing that Sykes had the burden of proving no deliberate bypass and of explaining why he did not object, Justice White concurred in the judgment only, ${ }^{48}$ urging the Court to develop a harmless-error rule of actual prejudice. In his view, requiring the state to show harmless error, in light of a constitutional violation, would adequately protect the state's interests. As to cause, Justice White was satisfied with the deliberate bypass rule, with the caveat that for bypass to occur the accused need not always agree with counsel's decision. ${ }^{49}$ He was thus in agreement with the Chief Justice and Justice Stevens in objecting to the Noia rule that petitioners be barred from habeas review only for defaults that were their own "considered choice." 50

\section{B. "Cause" in the Lower Federal Courts}

Wainwright $v$. Sykes has been discussed extensively by the federal courts of appeals. ${ }^{51}$ In possible efforts to avoid the uncharted seas of "cause and prejudice," 52 however, the courts of appeals frequently have rejected petitions on the merits rather than address the threshold test. ${ }^{53}$ Other courts have avoided confronta-

44 Noia looked to Zerbst in developing its deliberate bypass standard. See supra notes 6-7 and accompanying text.

45433 U.S. at 93 (Burger, C.J., concurring).

40 Id. 94.

47 Id. (Stevens, J., concurring).

$48 \mathrm{Id} .97$ (White, J., concurring in the judgment).

49 Id. 98-99.

50 See supra notes 6-7 and accompanying text.

51 The case had been cited in over 130 published court of appeals opinions by September 1, 1981. See also Tague, supra note 10, at 21-22 (if Sykes court had hoped to decrease the federal burden associated with habeas review, an undefined threshold test was not a wise choice).

52 See supra text accompanying note 34.

53 See, e.g., Williams v. Smith, 591 F.2d 169, 173 n.9 (2d Cir. 1979), cert. denied, 442 U.S. 920 (1979); Bryan v. Wainwright, 588 F.2d 1108, 1110 (5th Cir. 1979); Farrow v. United States, 580 F.2d 1339, 1356-57 (9th Cir. 1978); Spinkellink v. Wainwright, 578 F.2d 582, 591-92 (5th Cir. 1978), cert. denied, 440 U.S. 976 (1979); King v. Brewer, 577 F.2d 435, 437 (8th Cir. 1978), cert. 
tion by applying the Sykes bar without even mentioning the "cause and prejudice" exception. ${ }^{54}$

Relying on Chief Justice Burger's concurring opinion in Sykes, most courts discussing the "cause and prejudice" standard ${ }^{55}$

denied, 440 U.S. 918 (1979). See also Gale v. Harris, 580 F.2d 52, 53 n.1 (2d Cir. 1978) (per curiam) (court rejects petition on merits rather than deciding whether Sykes or Fay test applies), cert. denied, 440 U.S. 965 (1979).

54 See, e.g., Katz v. King, 627 F.2d 568, 577 (1st Cir. 1980); Gore v. Leeke, 605 F.2d 741, 743 (4th Cir. 1979) (alternative holding), cert. denied, 444 U.S. 1087 (1980); United States v. Anderson, 577 F.2d 258, 261 (5th Cir. 1978) (per curiam); United States v. Eldridge, 569 F.2d 319, 320 (5th Cir.) (per curiam), cert. denied, 436 U.S. 929 (1978); Loud v. Estelle, 556 F.2d 1326, 1329-30 (5th Cir. 1977); Nichols v. Estelle, 556 F.2d 1330, 1331 (5th Cir. 1977), cert. denied, 434 U.S. 1020 (1978).

55 Much discussion has been devoted to the other circumstances necessary before the "cause and prejudice" test comes into play: Courts have found the test inapplicable when failure to object at trial does not violate a procedural rule or result in default of state remedies, see, e.g., Washington v. Harris, 650 F.2d 447, 451 (2d Cir. 1981); Hicks v. Wainwright, 633 F.2d 1146, 1148 (5th Cir. 1981); Henson v. Wyrick, 634 F.2d 1080, 1081 (8th Cir. 1980), cert. denied, 101 S. Ct. 1417 (1981); Quigg v. Crist, 616 F.2d 1107, 1111 (9th Cir. 1980); Freeman v. Georgia, 599 F.2d 65, 68 (5th Cir. 1979), cert. denied, 444 U.S. 1013 (1980); Zapata v. Estelle, 588 F.2d 1017, 1021 (5th Cir. 1979); Tully v. Scheu, 607 F.2d 31, 33 (3d Cir. 1979), cert. denied, 102 S. Ct. 301 (1981); Brinlee v. Crisp, 608 F.2d 839, 857 (10th Cir. 1979), cert. denied, 444 U.S. 1047 (1980); Rummel v. Estelle, 587 F.2d 651, 653 (5th Cir. 1978) (en banc), aff'd, 445 U.S. 263 (1980); Singleton v. Lefkowitz, 583 F.2d 618, 626 (2d Cir. 1978), cert. denied, 440 U.S. 929 (1979); Codispoti v. Howard, 589 F.2d 135, 141 (3d Cir. 1978); when a state court reaches the merits of petitioner's allegedly defaulted claim, see, e.g., Thompson v. Estelle, 642 F.2d 996, 998-99 (5th Cir. 1981); Braxton v. Estelle, 641 F.2d 392, 394-97 (5th Cir. 1981) (per curiam); Gruttola v. Hammock, 639 F.2d 922, 926 (2d Cir. 1981); Hockenbury v. Sowders, 633 F.2d 443, 444-45 (6th Cir. 1980) (denying petition for rehearing en banc), cert. denied, 450 U.S. 933 (1981); Mitchell v. Smith, 633 F.2d 1009, 1011 (2d Cir. 1980), cert. denied, 449 U.S. 1088 (1981); Holloway v. McElroy, 632 F.2d 605, 617 (5th Cir. 1980), cert. denied, 451 U.S. 1028 (1981); Williams v. Zahradnick, 632 F.2d 531, 533 (5th Cir. 1980); Clark v. Blackburn, 632 F.2d 531, 533 (5th Cir. 1980); Soap v. Carter, 632 F.2d 872, 876 (10th Cir. 1980); Alburquerque v. Bara, 628 F.2d 767, 768 (2d Cir. 1980); Thomas v. Blackburn, 623 F.2d 383, 386 (5th Cir. 1980), cert. denied, 450 U.S. 953 (1981); Hockenbury v. Sowders, 620 F.2d 111, 112 (6th Cir. 1980), cert. denied, 450 U.S. 933 (1981); Baker v. Muncy, 619 F.2d 327, 329 (4th Cir. 1980); Babers v. Estelle, 616 F.2d 178, 179 (5th Cir.), cert. denied, 449 U.S. 985 (1980); Cook v. Bordenkircher, 602 F.2d 117, 119 (6th Cir. 1979), cert. denied, 444 U.S. 936 (1980); Bradford v. Stone, 594 F.2d 1294, 1296 (9th Cir. 1979); Burns v. Estelle, 592 F.2d 1297, 1301 (5th Cir. 1979); Cannon v. Alabama, 558 F.2d 1211, 1216 n.12 (5th Cir. 1977), cert. denied, 434 U.S. 1087 (1978); see also Rummel v. Estelle, 445 U.S. 263, 267 n.7 (1980); County Court of Ulster Co., N.Y. v. Allen, 442 U.S. 140, 148 (1979); a difficult inquiry in its own right, see, e.g., Ratcliff v. Estelle, 597 F.2d 474, 476 (5th Cir. 1979), cert. denied, 444 U.S. 868 (1980); Bradford v. Stone, 594 F.2d 1294, 1296 n.2 (9th Cir. 1979); Miller v. North Carolina, 583 F.2d 701, 705 (4th Cir. 1978); Collins v. Auger, 577 F.2d 1107, 1108-10 (8th Cir. 1978), cert. denied, 439 U.S. 1133 (1979); and when the state neglects to assert the Sykes bar in federal court, see Jenkins v. Anderson, 447 U.S. 231, 234 (1980); Smith v. Estelle, 602 F.2d 694, 701 (5th Cir. 1979), aff'd, 451 U.S. 454 (1981); Wynn v. Mahoney, 600 F.2d 448, 450 (4th Cir. 1979), cert. denied, 444 U.S. 950 (1980).

Courts have also debated what constitutes a sufficient objection to preclude use of the Sykes bar. See Mayola v. Alabama, 633 F.2d 992, 995 (5th Cir. 1980); 
have held the Sykes test to have displaced the Noia deliberate bypass test for defaults resulting from decisions that ultimately rest with defense counsel rather than the accused.56 Thus, the Sykes test is applied to all issues other than whether the defendant should testify, plead guilty, or waive a jury trial..$^{57}$

Those courts that actually have attempted to define the type of attorney conduct that will satisfy "cause" ${ }^{58}$ have reached vary-

Thomas v. Estelle, 582 F.2d 939, 940 (5th Cir. 1978); Suggs v. LaVallee, 570 F.2d 1092, 1096 (2d Cir.), cert. denied, 439 U.S. 915 (1978). The extent to which a state court's determination concerning the adequacy of the objection as a matter of state law is to be accepted as determinative of the Sykes question remains unclear. One court has found Sykes inapplicable when 2 state's rule is too "harsh." See Cheeck v. Bates, 615 F.2d 559, 562 (1st Cir.), cert. denied, 446 U.S. 944 (1980). Some judges would confine the Sykes rule to instances in which an objection is necessary to build a complete record surrounding the constitutional claim. See Runnels v. Hess, 653 F.2d 1359 (10th Cir. 1981) (Logan, J., dissenting); Cole v. Stevenson, 620 F.2d 1055, 1069 (4th Cir.) (Murnaghan, J., dissenting), cert. denied, 449 U.S. 1004 (1980). Still others would require trial judges not to permit certain procedural defaults to occur. See United States v. Powe, 591 F.2d 833, 843 n.31 (D.C. Cir. 1978). Also unanswered is whether a defendant's objection prevents the Sykes bar from operating against a non-objecting co-defendant. See Ashe v. North Carolina, 586 F.2d 334, 337 (4th Cir. 1978), cert. denied, 441 U.S. 966 (1979).

There is also disagreement whether Sykes applies to procedurally defaulted fourth amendment claims, see United States ex rel. Maxey v. Morris, 591 F.2d 386, 391 (7th Cir.), cert. denied, 442 U.S. 912 (1979); Johnson v. Meacham, 570 F.2d 918, 920 (10th Cir. 1978) (per curiam); Gates v. Henderson, 568 F.2d 830, 836-40 (2d Cir. 1977) (en banc), cert. denied, 434 U.S. 1038 (1978), and whether Sykes bars review in the case of "plain error," see Runnels v. Hess, 653 F.2d 1359 (10th Cir. 1981); Hockenbury v. Sowders, 633 F.2d 443, 444 (6th Cir. 1980), cert. denied, 450 U.S. 933 (1981); Brewer v. Overberg, 624 F.2d 51, 53 (6th Cir. 1980) (per curiam), cert. denied, 449 U.S. 1085 (1981); Krzeminski v. Perini, 614 F.2d 121, 123 (6th Cir.), cert. denied, 449 U.S. 866 (1980); Cook v. Bordenkircher, 602 F.2d 117, 119 (6th Cir. 1979), cert. denied, 444 U.S. 936 (1980); Rachel v. Bordenkircher, 590 F.2d 200 (6th Cir. 1978); Carr v. Alabama, 586 F.2d 462, 465 (5th Cir. 1978); Berrier v. Egeler, 583 F.2d 515, 519-24 (6th Cir. 1978), cert. denied, 439 U.S. 955 (1979); see also Wainwright v. Sykes, 433 U.S. at 99 (White, $\mathrm{J}$., concurring in the judgment).

50 See Beckham v. Wainwright, 639 F.2d 262, 265 (5th Cir. 1981); Myers v. Washington, 646 F.2d 355, 357-59 (9th Cir. 1981), vacated, 102 S. Ct. 1964 (1982); Crick v. Smith, 650 F.2d 860, 863 (6th Cir. 1981), cert. denied, 102 S. Ct. 1281 (1982); Graham v. Mabry, 645 F.2d 603, 605 (8th Cir. 1981); Guzzardo v. Bengston, 643 F.2d 1300, 1304 (7th Cir.), cert. denied, 452 U.S. 941 (1981); Wright v. Bombard, 638 F.2d 457, 459 (2d Cir. 1980) (per curiam), cert. denied 450 U.S. 935 (1981); Grace v. Butterworth, 635 F.2d 1, 5 (1st Cir. 1980), cert. denied, 452 U.S. 917 (1981); Rodgers v. Wyrick, 621. F.2d 921, 927 (8th Cir. 1980); Forman v. Smith, 633 F.2d 634 (2d Cir. 1980), cert. denied, 450 U.S. 1001 (1981); Boyer v. Patton, 579 F.2d 921, 927 (8th Cir. 1980); Harris v. Spears, 606 F.2d 639, 641-42 (5th Cir. 1979); Ferguson v. Boyd, 566 F.2d 873, 879 (4th Cir. 1977). See also Rosenberg, supra note 10, at 397 n.251.

57 See supra note 41 and accompanying text.

58 Most courts require a showing of "cause" and "prejudice," see, e.g., Graham v. Mabry, 645 F.2d 603, 608 n.3 (8th Cir. 1981); Tyler v. Phelps, 643 F.2d 1095, 1100 (5th Cir. 1981); Hockenbury v. Sowders, 620 F.2d 111, 112, on rehearing, - 633 F.2d 443 (6th Cir. 1980), cert. denied, 450 U.S. 933 (1981); Jurek v. Estelle, 
ing results. Some courts have attempted to give content to the term by referring to the Sykes concern "9 for avoiding a "miscarriage of justice"; ${ }^{80}$ but those same courts have given little hint as to what "miscarriage of justice" means."1 One court ${ }^{62}$ has said that a habeas petitioner must show that his attorney's failure to object amounted to "incompetence" in order to satisfy the "cause" prong. ${ }^{63}$ Although sixth amendment ineffectiveness of counsel has been held to satisfy the "cause" prong, courts finding such ineffectiveness have not discussed what else will satisfy "cause." 04

"Cause" has been held satisfied in other situations. In Collins v. Auger, ${ }^{65}$ the Eighth Circuit stated that an attorney's lack of knowledge of the facts or law underlying a claim satisfies Sykes cause, $^{68}$ but never defined the ambiguous "lack of knowledge of

593 F.2d 672, 681 (5th Cir. 1979), cert. denied, 450 U.S. 1001 (1981), but some courts have suggested that a showing of either cause or prejudice may suffice, see Thomas v. Estelle, 587 F.2d at 698; see also Wainwright v. Sykes, 433 U.S. at 95 (Stevens, J., concurring); Sumner v. Mata, 439 U.S. 112 (1980) (cause or prejudice in dictum). Other courts accomplish essentially the same end by employing a standard of "cause" that varies according to the extent of the prejudice shown. See Huffman v. Wainwright, 65I F.2d 347, 351 (5th Cir. 1981) (per curiam); Smith v. Estelle, 602 F.2d at 701 n.8; see also Goodman \& Sallet, Wainwright v. Sykes: The Lower Federal Courts Respond, 30 Hastings L.J. 1683, 1725 (1979). But see Tyler v. Phelps, 643 F.2d 1095, 1101 n.9 (5th Cir. 1981) ("cause" and "prejudice" independent).

59 See supra text accompanying note 36.

${ }^{60}$ See Huffman v. Wainwright, 651 F.2d 347, 348 (5th Cir. 1981) (per curiam) (citing Sincox v. United States, 571 F.2d 876, 880 (5th Cir. 1978)); Jiminez v. Estelle, 557 F.2d 506, 510-11 (5th Cir. 1977)); Harris v. Spears, 606 F.2d at 641-42.

61 "Miscarriage of justice" is not undefinable: The Court revealed a good deal about its sense of justice in Stone v. Powell, 482 U.S. 465 (1975) (habeas review generally not available for fourth amendment claims). The Court stated that "the disparity in particular cases between the error committed by the police officer and the windfall afforded a guilty defendant by application of the rule is contrary to the idea of proportionality that is essential to the concept of justice." Id. 490 (footnote omitted). See infra note 167.

62590 F.2d 153 (5th Cir. 1979) (per curiam).

${ }^{63} \mathrm{Id} .155$.

04 See United States v. Hearst, 638 F.2d 1190, 1196 (9th Cir. 1980), cert. denied, 451 U.S. 938 (1981); Rinehart v. Brewer, 561 F.2d 126, 130 n.6 (8th Cir. 1977).

Commentators have warned that the Supreme Court may be plagued with these issues in coming years-as petitioners increasingly use ineffectiveness complaints to avoid the Sykes bar of claims their attorneys have defaulted. See Rosenberg, supra note 10, at 418-47; Strazzella, Ineffective Assistance of Counsel Claims: New Uses, New Problems, 19 ARrz. L. Rev. 443, 476-84 (1977); Tague, supra note 10, at 56-66. The Court, therefore, may be forced to define the ineffectiveness standard, a task it has yet to confront, see infra note 169 and accompanying text.

65577 F.2d 1107 (8th Cir. 1978), cert. denied, 439 U.S. 1133 (1979).

66577 F.2d at 1110 \& n.2. 
the law." ${ }^{\circ 7}$ Courts similarly have held that defaults caused by "inadvertent mistake or neglect or the press of circumstance" satisfy cause, ${ }^{68}$ and have found that "ignorance" of a "significant constitutional right" is sufficiently "serious" to justify habeas review. ${ }^{69}$ The one clear point in this area is that the burden of proving "cause," 70 as well as "prejudice," 71 has been placed squarely on the shoulders of habeas petitioners. Substantial agreement as to what satisfies "cause," however, is lacking. The lower federal courts appear at odds as to how best to further the state's interests, as expressed in Sykes, while still protecting the petitioners'.

\section{What Sykes Conceals: State Control of Finality}

\section{A. The State's Finality Interest}

Federal habeas review of either procedurally defaulted constitutional claims or claims considered and rejected on their merits inevitably conflicts with the state's interest in finality. ${ }^{72}$ The state, of course, will always bear the initial cost of opposing habeas petitions. Even greater than this cost, however, is the cost the state bears if the petition is granted. The state must bear the cost of retrial: the cost of prosecution, the cost of providing the forum, and often the cost of defense. The burden of jury service falls on state residents. In addition to the financial burden, retrial disrupts state rehabilitative efforts. ${ }^{73}$ Federal habeas review

67 For discussion of a problem analogous to defining an attorney's "lack of knowledge of the law," see infra notes 99-101 and accompanying text (description of an "unintentional bypass").

68 Harris v. Spears, 606 F.2d at 643.

${ }^{69}$ See Jurek v. Estelle, 593 F.2d at 683.

70 See, e.g., Graham v. Mabry, 645 F.2d 603, 605 (8th Cir. 1981); Mendiola v. Estelle, 635 F.2d 487, 490 (5th Cir. 1981) (per curiam); Frazier v. Jago, 652 F.2d 57 (6th Cir. 1981); Jacks v. Duckworth, 65I F.2d 480, 485 (7th Gir. 1981), cert. denied, 102 S. Ct. 1010 (1982); Wright v. Bombard, 638 F.2d 457, 459 (2d Cir. 1980) (per curiam), cert. denied, 450 U.S. 935 (1981); Soap v. Carter, 632 F.2d 872, 876 (10th Cir. 1980), cert. denied, 451 U.S. 939 (1981); Pharr v. Israel, 629 F.2d 1278, 1280 (7th Cir. 1980), cert. denied, 449 U.S. 1088 (1981); Kemph v. Estelle, 621 F.2d 163, 163 (5th Cir. 1980) (per curiam), cert. denied, 450 U.S. 1000 (1981); Meyer v. Estelle, 621 F.2d 769, 771 (5th Cir. 1980); Conquest v. Mitchell, 618 F.2d 1053, 1054-56 (4th Cir. 1980); Parton v. Wyrick, 614 F.2d 154, 157 (8th Cir.), cert. denied, 449 U.S. 846 (1980); Ratcliff v. Estelle, 597 F.2d 474, 476 (5th Cir.), cert. denied, 444 U.S. 868 (1980); Lewis v. Cardwell, 609 F.2d 926, 927 (9th Cir. 1979); Buckalew v. United States, 575 F.2d 515, 520 (5th Cir. 1978); Crowell v. Zahadnick, 571 F.2d 1257, 1258 (4th Cir. 1977).

71 See, e.g., Ratcliff v. Estelle, 597 F.2d at 476.

72 See Bator, supra note 1, at 444-53; Tague, supra note 10, at 54 n.26.

73 Whether the mere possibility of retrial disrupts the rehabilitative process is disputed. Compare Schneckloth v. Bustamonte, 412 U.S. 218, 262-63 (1973) 
also interferes with the state's system of orderly administration of justice; in Wainwright $v$. Sykes the Court suggested that states lose the incentive to enforce procedural rules when defaulted claims can be reviewed on habeas. ${ }^{74}$ Thus finality is a legitimate concern of states. ${ }^{75}$

\section{B. The Sykes Court and the Finality Interest}

\section{What Sykes Can't Do}

The restrictive review approach to increasing the finality of state convictions-defining "cause" such that some or all unintentionally defaulted claims are not directly cognizable ${ }^{78}$ on habeas-has no impact on claims actually raised and rejected in the state courts; these remain directly cognizable on habeas.77 Nor would denying review of unintentionally defaulted claims increase the finality of state convictions by decreasing the number of frivolous habeas petitions. Although the state would assert the Sykes bar rather than argue the merits, any benefit to the state may be more apparent than real because the prisoner may file a habeas petition maintaining that counsel's default amounted to sixth amendment ineffectiveness, ${ }^{78}$ thus avoiding the Sykes bar. This "end-run" around Sykes may require the state to argue the merits of the procedurally defaulted claim on habeas because the validity of the claim may be relevant to whether failure to assert it constituted ineffective assistance of counsel. ${ }^{79}$

(Powell, J., concurring) (possibility of retrial disrupts focus on rehabilitation) with Freund, Symposium on Habeas Corpus, 9 UTAH L. Rev. 27, 30 (1964) (availability of collateral relief is a wholesome form of therapy).

74433 U.S. 72,89 (1977).

${ }^{75}$ See Schaefer, Federalism and State Criminal Procedure, 70 Harv. L. Rev. 1, 17-18 (1956). Schaefer, a Justice on the Supreme Court of Illinois, recognized three areas having federalism implications: the "flood" of frivolous habeas petitions, the "unseemliness" of a district court judge reviewing the decision of the highest state court, and the undue interference of habeas with the administration of criminal law.

70 To the extent that the unintentionally defaulted claim remains relevant in a habeas proceeding based on an ineffectiveness-of-counsel claim, the unintentionally defaulted claim is cognizable in an indirect manner.

77 The Sykes bar to habeas review applies only to procedurally defaulted claims. See supra note 55 and accompanying text.

78 See Tague, supra note 10, at 60-66; Strazzella, supra note 64, at 472-73.

79 See Tague, supra note 10, at 62-64 (the Supreme Court is likely to add a requirement that the attorney's error actually prejudice the defendant). Compare McMann v. Richardson, 397 U.S. 759 (1970) (post-conviction court should not review merits of the defaulted claim). 


\section{What Sykes Doesn't Do.}

In focusing on denial of habeas review of procedurally defaulted claims as a way to foster finality of state criminal convictions, $^{80}$ the Sykes Court failed to develop its assumption that attorneys generally act deliberately. ${ }^{81}$ If one accepts that assumption, denying habeas review for procedurally defaulted claims would foster finality by decreasing the number of procedural defaults that occur at trial.82 In the majority of cases, however, procedural default is not deliberate; ${ }^{83}$ elimination of habeas review of procedurally defaulted claims thus would deter procedural defaults only to the extent that attorneys would be more careful. This, of course, may decrease defaults somewhat-but at great cost to the unfortunate petitioner whose attorney will not, or cannot, use great care. Thus, the cost of increased finality is borne randomly by a few unlucky prisoners. ${ }^{84}$

In attempting to define "cause," the federal courts of appeals have not recognized that most procedural defaults are not deliberate, ${ }^{85}$ but rather have accepted the Sykes assumption. If the courts had recognized why procedural defaults actually occur, they would have seen the ways states themselves can increase finality in a manner similar to that which the Sykes Court contemplated-by decreasing the number of procedural defaults at the state trial level.

${ }^{80}$ See supra notes $23-50$ and accompanying text.

81 See infra notes 86-98.

82 Even if the number of procedural defaults decreases, state finality will be upset if the state fails to resolve the constitutional claim in the same way that the federal system would because habeas review generally remains available for fully litigated claims. See supra note 1 and accompanying text. Thus the Sykes court appears interested primarily in ensuring that the state get the first shot at constitutional claims that may upset the state's finality interest.

83 See infra notes 99-116 and accompanying text.

84 Cf. Wainwright v. Sykes, 433 U.S. at 113 (Brennan, J., dissenting) ("[u]nplanned and unintentional action of any kind generally is not subject to deterrence; and, to the extent that it is hoped that a threatened sanction addressed to the defense will induce greater care and caution on the part of trial lawyers, thereby forestalling negligent conduct or error, the potential loss of all valuable state remedies would be sufficient to this end.") (footnote omitted); The Supreme Court, 1976 Term, 91 HaRv. L. Rev. 70, 218 (1977); Rosenberg, supra note 10, at 415-16. Because a number of procedural defaults are caused by attorneys spending too little time per case, see infra notes 102-06 and accompanying text, some defaults can be deterred as long as an attorney is willing to increase the length of time he works. It seems unlikely, however, that a sanction applied to the client will motivate an attorney, in essence, to reduce his own standard of living. Sanctions applied directly to the attorney, however, may have an impact. See infra note 142 and accompanying text.

85 See infra notes 117-25 and accompanying text. 


\section{Myth and Reality: How Attorneys Operate}

That the federal courts of appeals have failed to produce a reasoned definition of the "cause" prong of the Wainwright $v$. Sykes test is not surprising. In Sykes the Supreme Court focused on the phenomenon of "sandbagging," but did not explore the more likely reasons for procedural defaults. The courts of appeals have followed the Supreme Court's lead in assuming that attorneys default claims, on the whole, deliberately.

\section{Where Sykes Goes Wrong}

The Sykes majority believed that the deliberate bypass rule of Fay $v$. Noia ${ }^{\mathbf{s}}$ encouraged defense lawyers to withhold federal constitutional claims and "take their chances on a verdict of not guilty in a state trial court with the intent to raise their constitutional claims in a federal habeas court if their initial gamble does not pay off." ${ }^{87}$ Since the Sykes decision, scholars have pointed out that practical considerations suggest that this phenomenon"sandbagging" ${ }^{88}$-occurs infrequently. ${ }^{89}$

A defendant who fails to raise a constitutional claim is subject to a number of sanctions other than denial of habeas corpus review, and thus has reason to hesitate before defaulting. The bypass of state procedural rules may prevent the defendant from raising a claim in the state appellate courts. ${ }^{90}$ To assume that the loss of such state appellate remedies fails to deter sandbagging suggests that defendants and their attorneys believe that the states, as a rule, do not adequately protect constitutional claims through their criminal appeals systems, a suggestion the Court has rejected in the context of fourth amendment claims. ${ }^{91}$ Even if defendants

${ }^{86} 372$ U.S. 91 (1963).

87433 U.S. at 89.

$88 \mathrm{Id}$.

$89 \mathrm{See}$, e.g., Tague, supra note 10 , at $43-46$.

90 Indeed, unless the bypass does result in default of state remedies, the Sykes rule does not bar habeas review. See supra note 55 .

91 See Stone v. Powell, 428 U.S. 465, 494 n.35 (1976):

Despite differences in institutional environment and the unsympathetic attitude to federal constitutional claims of some state judges in years past, we are unwilling to assume that there now exists a general lack of appropriate sensitivity to constitutional rights in the trial and appellate courts of the several States. State courts, like federal courts, have a constitutional obligation to safeguard personal liberties and to uphold federal law.

(citation omitted). 
or their attorneys decide to bypass certain claims, exhaustion-ofstate-remedies requirements ${ }^{92}$ may result in a lengthy period of incarceration before the deliberately bypassed constitutional claim can be raised in the federal forum. And when early release is possible through the operation of state processes, ${ }^{93}$. availability of federal habeas relief would seem to be little incentive for sandbagging. ${ }^{94}$

Even in the rare instance when the defense believes its case is bolstered by allowing a constitutional violation to go unaddressed, ${ }^{95}$ the defense would nonetheless benefit by raising the claim itself, thereby preventing the prosecution from introducing the evidence: "introduction by the prosecution as part of the state's case almost inevitably imprints on the minds of the jurors the notion that the confession [or evidence generally is] incriminating since, otherwise, the prosecution would presumably not have used it." 96 The defendant thus may lose a tactical advantage by failing to raise his claim. Additionally, the often-cited reason for failing to object at trial-fear that an objection will make the evidence appear more damaging than it otherwise would ${ }^{97}$-has no applicability in many situations because of the availability of pretrial proceedings and motions in limine. Even when suppression of the fruits of a constitutional violation seems unimportant in itself, resort to pretrial proceedings permits the defense to engage in a limited form of pretrial discovery. ${ }^{98}$ In the end, the defendant has more to lose from a default than the Sykes Court took into account.

92 See 28 U.S.C. $\$ 2254$ (b)-(c) (1976).

93 The median time for disposition of a state habeas petition in federal district court is two months, see Rosenberg, supra note 10 , at $423 \mathrm{n} .341$, but even if the petition is granted, the prisoner may be required to remain in prison pending disposition of the state's appeal of the district court ruling.

94 For example, in Isaac v. Engle, $102 \mathrm{~S}$. Ct. 1558 (1982), two of the three habeas petitioners whose cases were consolidated on certiorari had been granted parole and subsequently received final releases prior to appeal of their cases. See Brief for Petitioner at 8-9.

95 See Wainwright v. Sykes, 433 U.S. at 96 (Stevens, J., concurring) (statement allegedly obtained in violation of Miranda rule was consistent in many respects with accused's trial testimony and 'had some positive value, since it portrayed the [accused] as having acted in response to provocation, which might have influenced the jury to return a verdict on a lesser charge.").

96 Rosenberg, supra note 10, at 404.

97 See, e.g., Wainwright v. Sykes, 433 U.S. at 97 (Stevens, J., concurring).

98 See Rosenberg, supra note 10, at 403. See also F. BAIIEY \& H. ROTHBLATT, Investigation and Preparation of Crmminal Cases $\$ \$ 324,352$ (1970). 


\section{How Procedural Defaults Really Happen}

Because of the practical disadvantages of "sandbagging," 99 a defense attorney will rarely commit deliberate bypass in the true sense ${ }^{100}$-that is, intentionally relinquishing one of the defendant's known rights or privileges. ${ }^{101}$ Rather, most procedural bypasses are probably unintentional.

One type of default is caused by the attorney's lack of information; the attorney simply may be unaware of the factual basis of a potential claim. On the other hand, the attorney could be fully aware of the factual (and the legal) bases of a constitutional claim but default it through ignorance of the procedural requirements for preserving it. Still another mistake would occur if the attorney knew the facts, but erroneously concluded that they had no bearing on the case. Such decisions often result from a lack of time to prepare a case fully.

Time pressures probably are felt strongest by those attorneys representing indigents. ${ }^{102}$ Typically, those attorneys are with a public defender's office ${ }^{103}$ or are private attorneys working through legal aid societies or a court-appointment system. ${ }^{104}$ Regardless of whether an attorney is public or private, inadequate compensation for representing indigents impedes effective representation.

99 See supra notes 86-98 and accompanying text.

100 When it is committed, however, the test proposed by this Comment would bar habeas review because the petitioner would carry the burden of disproving deliberate bypass. To the extent that sandbagging is likely, then, the proposed test would discourage it.

101 Cf. Johnson v. Zerbst, 304 U.S. 458, 464 (1938) (defining waiver as "an intentional relinquishment or abandonment of a known right or privilege"). The Noia Court suggested that a deliberate bypass could occur only when the decision to relinquish the right was made by the accused. See supra text accompanying note 6. But the Sykes Court rejected that approach, see supra text accompanying notes 24-27, apparently giving defense counsel the power to bind the accused on the basis of counsel's deliberate bypass.

102 Over 60 percent of the defendants who had public defenders reported in a recent study that their attorney had spent less than one-half hour with them; almost 30 percent put the figure at less than ten minutes. See J. Casper, Criminat Courts: The Defendant's Penspective iv (1978) (abstract), reprinted in Y. Kamisar, W. LaFave \& J. Israez, Modern Crummar Procedure 90 (5th ed. 1980). See also Bazelon, The Realities of Gideon and Argersinger, 64 GEO. L.J. 811 , 817-18 (1976) (attorney indifference and overwork "most frequent" causes of ineffective representation).

${ }^{103} \mathrm{~A}$ public defender's office is "headed by a public official and supported by public funds." Friloux, Equal Justice Under the Law: A Myth, Not a Reality, 12 AM. Crum. L. REv. 691, 695 (1975) (footnote omitted). See generally, Wice \& Suwak, Current Realities of Public Defender Programs: A National Survey and Analysis, 10 Cram. L. Buli. 161 (1974).

104 See J. Casper, Amertcan Crmminal Justice: The Defendant's PerspecTTVE 102 (1972); see also Friloux, supra note 103, at 695. 
In the private system, for example, attorneys serving in court appointments earn far less than they would billing private clients. This economic disincentive forces attorneys to minimize time spent on court appointments. ${ }^{105}$ Attorneys whose practices consist almost exclusively of court appointments at relatively low hourly rates must increase their work week to keep pace with their peers; the resultant overwork may lessen the attorneys' effectiveness. ${ }^{106}$ In addition to the general problem of low reimbursement, court appointments may use reimbursement schemes that dissuade thorough factual and legal research by rewarding attorneys who spend a high percentage of their time in the courtroom: as Judge Bazelon has noted, ${ }^{107}$ the federal Criminal Justice Act discourages full preparation of cases not only by reimbursing attorneys at a low rate, but also by reimbursing them at a lower rate for out-ofcourt work than for courtroom duty. ${ }^{108}$

The better-known public defender system has received some academic attention in the wake of Argersinger $v$. Hamlin, ${ }^{109}$ in which the Supreme Court extended the Gideon $v$. Wainwright ${ }^{110}$ guarantee of legal counsel to misdemeanants. ${ }^{111}$ This attention has done nothing to alleviate the severe economic pressure on the system. Commentators point to inadequate funding as one of the public defender system's greatest weaknesses. ${ }^{112}$ Because of limited funding, many public defender's offices are understaffed; the resulting caseloads are often unmanageable. ${ }^{113}$ Further, little time is

105 In Connecticut, where court-appointed attorneys are paid $\$ 12.50$ per hour, one attorney estimated that representing an indigent murder suspect cost the attorney $\$ 20,000$ in potential earnings and forced him "to give up his solo practice and join a firm." Bar Talk: A Going Rate of $\$ 12.50 / H r$., AM. LAw., Oct. 1981, at 16 . The attorney, who spent 500 hours on the case, including a ten-week trial, plans to withdraw from representing the indigent suspect in the new trial the attorney won by showing that one of the jurors in the first trial had intentionally withheld information during voir dire. Id.

106 See Bazelon, supra note 102, at 817-18.

107 United States v. Decoster, 624 F.2d 196, 279 n.80 (D.C. Cir. 1979) (en banc) (Bazelon, J., dissenting).

10818 U.S.C. $\$ 3006 \mathrm{~A}(\mathrm{~d})(\mathrm{I})(1976)$. Under the Act, court-appointed attorneys receive a maximum of $\$ 30$ per hour for courtroom time and $\$ 20$ per hour for out-of-court time.

109407 U.S. 25 (1972).

110372 U.S. 335 (1963).

111 See generally Friloux, supra note 103, at 700-01; Wice \& Suwak, supra note 103 , at 183 . 182-83.

112 See Friloux, supra note 103, at 700-01; Wice \& Suwak, supra note 103, at

113 See Bazelon, supra note 102, at 815; J. CASPER, supra note 104, at 103. 
available to interview the client to learn fully the facts of his case. ${ }^{114}$ Lower salaries mean less recruiting power at law schools; at the very least young lawyers choosing to work as public defenders usually remain in the system for only a short period of time after graduation. The staff in many offices is therefore inexperienced.115 Few training and continuing education programs are offered to help alleviate the situation. ${ }^{116}$

\section{Blinders on the Deaf: An Example of the Courts' Acceptance of Sykes}

Despite the protestations of scholars, ${ }^{117}$ the federal courts of appeals have ignored the most likely reasons that procedural defaults occur, $^{118}$ relying instead on the Sykes assumption that attorneys almost always act deliberately. The result is two-fold: First, because the courts do not acknowledge the other reasons procedural defaults occur, they never consider how their definitions of "cause" actually affect the frequency of procedural default.119 Second, much of the discussion focuses on inaccurate assumptions about the effects resulting from a particular definition of "cause." Courts assume, for example, that one definition will deter certain undesirable attorney behavior.

The debate in the change-of-law cases ${ }^{120}$ illustrates the ways courts reason. The change-of-law cases involve procedural defaults that occur prior to an event-such as a United States Su-

114 See Bazelon, supra note 102, at 815.

115 See Bazelon, supra note 102, at 815; Wice \& Suwak, supra note 103, at 165.

116 See Bazelon, supra note 102 , at 815, citing Wice \& Pilgrim, Meeting the Gideon Mandate: A Survey of Public Defender Programs, 58 Judicature 400, 402 (1975); Wice \& Suwak, supra note 103, at 165. $43-46$.

117 See, e.g., Rosenberg, supra note 10, at 403-05; Tague, supra note 10, at

118 See supra text accompanying notes 99-116.

119 See infra notes 120-26 and accompanying text.

120 Compare Myers v. Wash., 646 F.2d 355 (9th Cir. 1981), vacated, 102 S. Ct. 1964 (1982); Isaac v. Engle, 646 F.2d 1129 (6th Cir. 1980), rev'd, 102 S. Ct. 1558 (1982); Williams v. Martin, 618 F.2d 1021 (4th Cir. 1980); Bell v. Perini, 636 F.2d 575 (6th Cir. 1980), rev'd, 102 S. Ct. 1558 (1982); United States v. Frady, 636 F.2d 506 (D.C. Cir. 1980), rev'd, 102 S. Ct. 1584 (1982), in all of which habeas was granted, with Taylor v. Harris, 640 F.2d 1 ( $2 \mathrm{~d}$ Cir.), cert. denied, 452 U.S. 942 (1981); Cole v. Stevenson, 620 F.2d 1055 (4th Cir.) (en banc), cert. denied, 449 U.S. 1004 (1980); Carter v. Jago, 637 F.2d 449 (6th Cir. 1980); Lewis v. Cardwell, 609 F.2d 926 (9th Cir. 1979); Frazier v. Weatherholtz, 572 F.2d 994 (4th Cir.), cert. denied, 439 U.S. 876 (1978), in all of which habeas was denied. 
preme Court decision-making clear that the defaulted claim was indeed valid. The question is whether the "cause" prong of Sykes is satisfied in such a case. ${ }^{121}$ An example reveals the character of the courts' analysis of the "cause" issue. In Myers $v$. Washington, ${ }^{122}$ defense counsel failed to object at trial to jury instructions that shifted the burden of proof of self-defense from the state to the accused. At that time, the Supreme Court had not made a definitive ruling on the issue. After the procedural default occurred, the Supreme Court held in Mullaney v. Wilbur ${ }^{123}$ that such burden-shifting jury instructions violate the accused's due process rights. The Myers court divided on whether the failure to anticipate the Mullaney ruling satisfied the cause prong of Sykes; the majority found the unsettled state of the law sufficient to satisfy "cause" and permitted habeas review. The majority permitted habeas review in the change-of-law circumstance because to have done otherwise would "simply encourage defense attorneys to raise on appeal every conceivable constitutional challenge that might some day be accepted-and thus overload their briefs with unmeritorious issues." 124 The majority assumed its holding would limit such challenges. The dissent argued that the majority's rule removes the attorney's incentive to foster legal evo-

121 The Supreme Court recently answered this question in the negative. See Engle v. Isaac, 102 S. Ct. 1558 (1982). Despite the allegations of the habeas petitioners that they "could not know that Ohio's self-defense instructions raised constitutional questions," the Court found that the possible claims "were far from unknown at the time of their trials." Id. 1573. Thus the "cause" prong was not satisfied. Stressing the special concerns associated with habeas review, Justice O'Connor, writing for the majority, said:

[T]he Constitution guarantees criminal defendants only a fair trial and a competent attorney. It does not insure that defense counsel will recognize and raise every conceivable constitutional claim. Where the basis of a constitutional claim is available, and other defense counsel have perceived and litigated that claim, the demands of comity and finality counsel against labelling alleged unawareness of the objection as cause for a procedural default.

Id. 1573-74. How many "other defense counsel" must "perceive and litigate[]" the claim is uncertain.

Emphasizing that "[T]h[e] claim did not exist at any time during Isaac's trial or direct appeal," id. 1579, Justice Brennan penned a scathing dissent:

I hope that the Court forgets only momentarily that "the States' sovereign power" is limited by the Constitution of the United States: that the "intrusion" complained of is the supreme law of the land. But it must be reason for deep concern when this Court forgets, as it certainly does today, that "it is a constitution we are expounding, .... .

Id. 1582, citing M'Culloch v. Maryland, 17 U.S. (4 Wheat.) 316, 407 (1819).

122646 F.2d 355 (9th Cir. 1981), vacated, 102 S. Ct. 194 (1982).

123421 U.S. 684 (1975).

$124646 \mathrm{~F} .2 \mathrm{~d}$ at 360 . 
lution through presentation of innovative claims. By removing the penalty of lost habeas review for procedural defaults of unestablished claims, the dissent posited, the court encourages attorneys to rely on "mere rote recitations of hornbook legal principles." ${ }^{125}$ This Comment challenges the assumption, made by both sides, that the new rule would affect attorney behavior. ${ }^{126}$

\section{The State's Control}

Analysis of how procedural defaults actually occur reveals that the states can, if they so desire, ${ }^{127}$ decrease procedural defaultsand thus increase finality-in ways unavailable to the federal courts. ${ }^{128}$ Increased funding of public defender's offices would ease heavy caseloads, ${ }^{329}$ and higher rates of reimbursement for court-appointed attorneys, as well as revision of pay scales that discourage thorough investigation of the legal and factual bases of potential claims, would encourage attorneys with private practices not to slight their court-appointed cases, ${ }^{130}$ lessen the workload of attorneys whose practices consist almost exclusively of court appointments, ${ }^{131}$ and encourage out-of-court preparation by courtappointed attorneys.132 Increasing the time court-appointed counsel can spend with a client would likely lessen the client's mistrust of the attorney, facilitating investigation of the factual bases of potential claims. ${ }^{133}$ Higher salaries ${ }^{134}$ for public defenders would

125 Id. 364 (Poole, J., dissenting).

126 See infra notes 158-65 and accompanying text.

127 For a discussion of when a state will not elect to foster finality, see infra notes $143-48$ and accompanying text.

128 The Noia reign was known to have exerted indirect pressure on states to reform their own post-conviction remedies in an effort to reduce the number of cases diverted to federal courts on habeas. See Meador, The Impact of Federal Habeas Corpus on State Trial Procedures, 52 VA. L. Rev. 286, 297-98 (1966) ("If Noia and Townsend remain unimpaired they might similarly influence a nationwide reform in state criminal trial procedures . ...").

129 See supra text accompanying notes 112-13.

130 See supra text accompanying note 105.

131 See supra text accompanying note 106.

132 See supra text accompanying notes 107-08.

133 See supra note 102.

134 Salaries for government attorneys are traditionally far lower than those available to new associates at large law firms. In 1980, for example, a law school graduate joining one New York City firm earned $\$ 39,981$. If the same graduate joined the New York County District Attorney's Office, the graduate would earn $\$ 18-20,000$. Questionnaires Filed through the National Association of Law Placement Offices. The latter figure is probably comparable to the pay of public de- 
attract more talented ${ }^{135}$ young lawyers to public defender's offices and encourage them to stay, ${ }_{136}$ increasing the experience of the public defender's staff.

Other options available to the state would decrease the number of procedural defaults by private as well as public attorneys. The state designs its own procedural rules; simplification of those rules would decrease the number of constitutional claims an attorney defaults out of ignorance of the proper procedure. ${ }^{13 \tau}$ States also control admission to practice; they can use that power to increase the competency required before admission or to impose continuing education requirements on the criminal bar to ensure familiarity with recent legal developments. ${ }^{138}$ The educational effort could range from requirements of recertification to publication of a periodic newsletter canvassing pertinent new case law. A similar end could be achieved by alerting judges to recent legal developments and charging them to remind counsel of potential constitutional challenges that are about to be defaulted; ${ }^{139}$ the

fenders; in general, salaries offered in both offices are competitive with each other. See Wice \& Suwak, supra note 103, at 166.

135 See supra text following note 114.

136 The lure of more money in the private sector may lead attorneys to leave government service just as they are gaining the experience to function most effectively. For example, only three percent of the attorneys at the New York County District Attorney's Office have been there more than ten years, $21 \%$ for more than five years, and 65\% for more than two years. See Questionnaire, supra note 134.

137 See supra text following note 101.

138 Some question exists, however, whether continuing legal education alleviates ineffective representation. Judge Bazelon suggests that "neither specialization nor continuing [legal] education is addressed to the problems of indifference and overwork, yet ... these are the most frequent causes of the ineffective representation many indigent defendants receive." Bazelon, supra note 102, at 818 (footnote omitted). Another commentator postulated that continuing legal education will not "meet the challenges of advancing the competency" of attorneys. Wolkin, A Better Way to Keep Lawyers Competent, 61 A.B.A. J. 574, 575 (1975). Wolkin went on to say that "mere attendance at continuing legal education courses will not necessarily enhance competence. Presence is not evidence of learning. . . . [T] ber of hours being prescribed is so minimal that it is difficult to perceive any longlasting benefits related to enhancing competence." Id. 575-76. Wolkin recommended a system that would include selective monitoring of competence, voluntary peer review, and effective voluntary continuing legal education. Wolkin, More on $a$ Better Way to Keep Lawyers Competent, 61 A.B.A. J. 1064 (1975). Not all authorities are as pessimistic about the value of mandatory legal education programs. The Judicial Conference of the Second Circuit, for example, advocated a mandatory program of study (either in law school or as continuing legal education) as a prerequisite for practicing in district court. Each lawyer would be required to take courses in evidence, civil procedure, criminal law and procedure, professional responsibility, and trial advocacy. These recommendations-the Clare Committee Report-were summarized in New Admission Rules Proposed for Federal District Courts, 61 A.B.A. J. 945 (1975).

${ }^{139}$ See Spritzer, Criminal Waiver, Procedural Default and the Burger Court, 126 U. PA. L. Rev. 473, 510-11, 514 (1978). By finding no fault with the trial judge's failure to raise an objection to admission of the statement in Sykes, 433 
states could even develop a checklist to be reviewed in court before trial to remind counsel of potential constitutional objections. ${ }^{140}$ Finally, one commentator has suggested that state courts can increase finality by making a complete record for the reviewing habeas court. ${ }^{141}$ Under a system that allows review for unintentional defaults, for example, a complete record can make clear that a default was in fact intentional.

After a procedural default occurs, the state may guard its finality interest in a prospective manner. By notifying the attorney who committed the procedural default, the state decreases the likelihood that the attorney will default similar claims in the future; inveterate defaulters ${ }^{142}$ could be threatened with disbarment and ultimately be disbarred, a move certain to decrease the number of inveterate defaulters practicing in the state.

The state thus has at its command numerous tools for promoting its own finality interest. When habeas review is available for all unintentionally defaulted claims, the rational state's decision as to how to promote that interest is analogous to the manufacturer's decision about how to increase worker safety under a regimen of strict liability for accidents in the workplace. Manufacturers do not provide their employees with the safest equipment imaginable. Instead, the manufacturers determine whether it is cheaper for them to pay damages when workers are injured or to reduce the outlay for damages by spending money to obtain safer equipment. ${ }^{143}$ Economically rational manufacturers take the course that decreases their total costs; ${ }^{\mathbf{1 4 4}}$ that course, however, may not be the one that decreases accidents. ${ }^{145}$

U.S. at 91, the Court suggests that there might be occasions when the trial judge's failure to object sua sponte might make the cause-and-prejudice test inapplicable. An affirmative role for the judge was also advanced in Meador, supra note 128, at 293 (1966). "[B]y developing certain new behavior patterns the trial judge can increase substantially the probability of finality."

${ }_{140}$ Cf. Tigar, Waiver of Constitutional Rights: Disquiet in the Citadel, 84 HaRv. L. REv. 1, 23 (1970) (urging judges to ask defendants a list of questions before accepting their guilty pleas), quoted in Spritzer, supra note 139, at 495 n.114.

141 Meador, supra note 128, at 291-92 (1966); see also Townsend v. Sain, 372 U.S. 293 (1963) (habeas court may direct a new evidentiary hearing).

142 Frequent defaulters may violate rules requiring diligent investigation of the legal and factual bases of potential constitutional claims. See, e.g., ABA STANDARDS, supra note $41, \S \$ 4.1$, at $225-26$ (duty to investigate facts), 5.I(a), at 234 (duty to advise defendant after fully informing himself on the facts and the law).

143 If safer equipment cost manufacturers no more, of course, they would use it. 144 The manufacturers' total cost equals the cost of their equipment plus the damages they must pay for injuries to their workers.

145 See G. Calabresi, The Costs of Acciofents 18 (1970) (Manufacturers "use relatively safe equipment rather than the safest imaginable because-and it is not a bad reason-the safest costs too much."). 
In a similar fashion, states in a system that allows habeas review of procedurally defaulted claims will not attempt simply to increase finality: the state has other goals to consider, such as "reducing erroneous judicial decisions" 146 and minimizing the cost of its justice system.

Before using one of its tools to decrease procedural defaults, therefore, the state will balance the cost of using the method against the resulting benefits of increased finality. If the cost is less than the total benefit, the state should use the tool to reduce procedural defaults. If, however, the use of a certain tool costs more than refraining from its use, the state may find the cost associated with decreasing the mistrials prohibitive. What results is a compromise; neither goal is maximized, but each is pursued to a limited degree.

The state is in the best position to balance the goals. First, the state is the party that bears the cost of retrial; it is therefore best able to calculate the cost associated with decreased finality. Second, because the state always knows when a habeas petition has been granted to a state prisoner, it is in the best position to determine whether any of its attempts to decrease procedural defaults has indeed increased finality; if ineffective, the programs may be modified or eliminated. Third, the state is best able to calculate the cost associated with any given reform: ${ }^{147}$ for example, the cost of running continuing education programs, the cost of freeing attorneys to attend the sessions, and even the cost to the state of having to process additional constitutional claims at the trial level. ${ }^{148}$ The state has greater access to all this information than do federal courts.

${ }_{146}$ On the other hand, the state will not be able to reduce the error rate to zero because of the costs which would be associated with such a procedural system. See R. Posner, Economic ANalysis of Law 429 (2d ed. 1977). Similarly, the state may not be able to increase finality to the greatest extent possible because of prohibitive costs.

147 The costs may be difficult to ascertain. For example, although increasing the number of claims that private attorneys must raise would have no direct effect on the state in terms of the cost of providing defense, the sanctions necessary to enforce such a program would decrease the pool of private defense attorneys and thereby increase the cost of private criminal counsel. That would result in a higher percentage of defendants being unable to retain private counsel, increasing the number of persons that the state will be required to defend. An increase in the cost of private counsel would also necessitate proportionally higher rates of compensation to private attorneys retained to defend indigent clients; otherwise, those attorneys would be disinclined to investigate cases fully because they are paid at a higher rate in their private capacity.

148 This cost is increased to the extent that a reform generates a high ratio of fruitless to fruitful claims. 


\section{The Case for federal Habeas Review of Unintentionally Defaulted Constirutional Glaims}

Wainwright $v$. Sykes ${ }^{149}$ makes clear that federal district courts are not to entertain habeas petitions from petitioners whose attorneys were "sandbagging"-that is, committing deliberate bypasses of state procedures for raising the federal constitutional

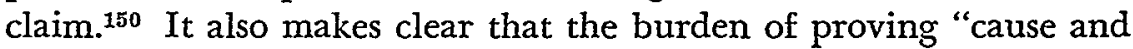
prejudice" falls on the petitioner. ${ }^{151}$ What remains to be decided is the extent to which unintentional bypasses should bar habeas review. 152 This Comment proposes that the "cause" prong of Sykes be considered satisfied whenever a petitioner shows that a procedural default is unintentional. ${ }^{153}$ A contrary approach removes incentives to the states to decrease procedural defaults. It also increases the need for federal courts to process claims of ineffective assistance, thereby placing the responsibility for shaping legal delivery systems on a party not well suited to designing the most effective system. ${ }^{154}$

149433 U.S. 72 (1977).

150 Deliberate bypasses barred habeas review even under the Noia rule, see supra text accompanying notes, and the Sykes test is "narrower" than the Noia test, see supra note 35 and accompanying text. See also supra notes 23-36 and accompanying text.

151 In Sykes, the Court held only that the cause prong of the threshold test was not met when petitioner failed to explain why the constitutional claim was bypassed. See supra note 33 and accompanying text. Therefore, Sykes establishes that the initial burden is on the petitioner, not the state, to explain why the procedurally defaulted claim was not raised. See also Sykes, 433 U.S. at 99 (White, $\mathrm{J}$., concurring in the judgment) (burden on petitioner).

152 One commentator has urged that the Court adopt a "reasonableness" standard-that is, that habeas review be permitted whenever an attorney unreasonably commits a procedural default of a federal constitutional claim. "The reasonableness standard . . . would ... focus on the specific error committed by the petitioner's counsel. The test would be whether, in light of the specific circumstances surrounding the single act of nonobjection, the attorney acted reasonably." Note, Attorney Error as "Cause" under Wainwright v. Sykes: The Case for a Reasonableness Standard after Washington v. Downes, 67 VA. L. Rev. 415, 427 (1981). Because a procedural default can be unintentional but nonetheless reasonable, however, see supra notes 100-03 and accompanying text, the reasonableness test would eliminate habeas review for some unintentionally procedural defaults.

153 The Virginia note does not discuss the possibility of defining "cause" in such terms; it presumes that the only alternative to a "reasonableness" test is an "ineffectiveness" test. See generally Note, supra note 152. The "unintentional default" standard proposed here would apply whether the default was reasonable or not.

154 In an effort to protect the constitutional rights of prisoners, federal courts may recognize such claims. The ineffectiveness of counsel "bypass" is unsatisfactory, however, in a number of ways. For example, the defendant, the party in the worst position to choose efficient solutions to the procedural default problem, would bear the burden of promoting litigation of constitutional claims. Experimentation 
A. The Problems with Promoting Finality of State Convictions

by Denying Habeas Review of Certain Procedurally

Defaulted Claims

Promoting the state's finality interest by denying habeas review of some unintentionally defaulted claims is inferior to providing habeas review for all unintentionally bypassed claims and leaving the state to determine how to protect its finality interest. ${ }^{155}$ Each of the parties involved-the state, the attorney, the prisoner, and the federal courts-is unfavorably affected by a system in which finality is maximized by denying habeas review of some unintentionally defaulted claims.

\section{Effects on the State}

When habeas review is unavailable for procedurally defaulted claims, the state loses its incentive to increase the quality of the criminal bar or otherwise decrease procedural default because the state's finality interest largely would be satisfied. The state would derive no further benefit of increased finality from the expenditures necessary to decrease defaults. ${ }^{156}$ With less incentive, the state is not encouraged to use its control over procedural defaults 157 to decrease those defaults. More procedural defaults lessen the workload of the state courts by decreasing the substantive claims they process. Public attorneys could also handle more cases. The state thus will not do all it could to reduce procedural defaults if habeas review is unavailable.

\section{Effects on the Attorney}

The elimination of habeas review authorized by Wainwright v. Sykes was aimed largely at deterring defense counsel from "sandbagging." 158 Because sandbagging is predicated on the existence of habeas review for the procedurally defaulted claim, ${ }^{159}$ elimi-

in how best to deliver legal services would be discouraged, and use of the ineffectiveness claim would skew the definition of ineffectiveness and increase state-federal friction.

155 See supra notes $143-48$ and accompanying text.

156 The state will pay the cost necessary to decrease procedural defaults when that cost is less than the benefit that would accrue to the state if defaults decrease. See supra notes 143-48 and accompanying text. Costs, of course, may be social as well as economic.

157 See supra notes $127-42$ and accompanying text.

158 See supra text accompanying notes 23-38.

159 By definition, sandbagging occurs only when defense counsel is saving the claim for a possible habeas challenge. See supra text accompanying note 28 . 
nating habeas review of deliberately defaulted claims would eliminate the possibility of sandbagging.

Eliminating habeas review of unintentionally defaulted claims, on the other hand, is not likely to decrease materially the number of defaults an attorney commits. This failure is not explained simply by saying that unintentional defaults cannot be deterred; ${ }^{100}$ indeed, attorneys probably can decrease the number of defaults somewhat. Analysis of why procedural defaults occur ${ }^{161}$ suggests that individual attorneys could eliminate at least some of them. For example, if an attorney could work longer hours without ceasing to be effective, the attorney could avoid those defaults caused by spending too little time per case: ${ }^{162}$ the attorney could simply put in more time. Attorneys could likewise avoid those defaults caused by lack of knowledge of recent legal developments by undertaking self-imposed continuing education regimens, such as reading professional journals or attending seminars. ${ }^{163}$

Attorneys, however, may not take such steps to decrease procedural defaults. Each step carries a cost to the attorney: it reduces the time available for other activities, whether professional or personal, and may carry other, more tangible costs, such as seminar enrollment fees. The attorney may decide to pay that cost only if it is less than the corresponding benefit. ${ }^{164}$ The potential inability to obtain habeas review of a defaulted claim is therefore unlikely to stir the attorney to undertake the cost of avoiding default; not only is the brunt of the penalty for procedural default absorbed by the client, but the attorney, who no doubt will assert some defense for his client, may believe that pressing additional claims rarely will be fruitful. ${ }^{165}$

160 But see Rosenberg, supra note 10, at 415-16: "[T] is inapplicable to attorneys who commit defaults as a result of negligence or ignorance. These lawyers cannot possibly be deterred by the imposition of a forfeiture against their clients." See also The Supreme Court, 1976 Term, 91 Harv. L. Rev. 70, 217-18 (1977) ("There is good reason to believe that sandbagging is not often a useful tactic, and that in any event federal courts are sufficiently able to deter it. The most likely explanation for procedural defaults, then, is attorney error.") (footnotes omitted); Wainwright v. Sykes, 433 U.S. at 113 (Brennan, J., dissenting) ("Punishing a lawyer's unintentional errors by closing the federal courthouse door to his client is both a senseless and misdirected method of deterring the slighting of state rules. ... [u]nplanned and unintentional action of any kind generally is not subject to deterrence ....").

161 See supra notes 99-116 and accompanying text.

162 See id.

163 But see supra note 138.

104 The attorney's decision is analogous to the state's discussed supra notes 143-48 and accompanying text.

165 Although the approach of denying review of unintentional defaults may not alter attorney conduct, the state, because of its superior power over the attorney, 


\section{Effects on the Prisoner}

If all claims lost through unintentional procedural default were cognizable on habeas, the cost of imperfections in the mechanism for preserving valid constitutional claims would be borne by the state in the form of retrial costs. The state would spread those costs across society by taxation. Under the restrictive-review approach, however, the costs of default fall on those prisoners whose attorneys failed to raise the valid claim. Because a client's factual guilt is not related to whether his attorney commits procedural defaults, ${ }^{166}$ even prisoners whose defaulted claims are guilt-related must bear the cost, namely incarceration, when a good chance exists that absent the default they would have not have been found guilty. Considering the Court's view of habeas as most valuable when protecting the innocent from unconstitutional incarceration, ${ }^{167}$ such a result would be curious at best.

\section{Effects on the Federal Courts}

Federal courts, ${ }^{168}$ if concerned about preserving constitutional rights, may believe it necessary to interfere in a system in which unintentional defaults fail to satisfy the "cause" requirement. To

could persuade attomeys to take steps to avoid default by increasing the penalty for defaulting. See supra notes 139-42 and accompanying text.

166 Indeed, an attorney who fails to raise a claim because of his belief in the guilt of his client has provided ineffective assistance. "The lawyer, who refuses his professional assistance because in his judgment the case is unjust and indefensible, usurps the function of both judge and jury." G. Starswoon, Pronessronat. Etrrics, reprinted in 32 A.B.A. Rep. 33-84 (1907). See also ABA Standarns, supta note $41, \S 4.1$, at 226 (lawyer under duty to investigate "regardless of the accused's admissions or statements to the lawyer of facts constituting guilt").

107 See Stone v. Powell, 428 U.S. 465, $491-92$ n.31 (1976):

"We ... afford broad habeas corpus relief, recognizing the need in a free society for an additional safeguard against compelling an innocent man to suffer an unconstitutional loss of liberty. The Court in Fay $v$. Noia described habeas corpus as a remedy for "whatever society deems to be intolerable restraints," and recognized that those to whom the writ should be granted "are persons whom society has grievously wronged." But in the case of a typical Fourth Amendment claim, asserted on collateral attack, a convicted defendant is usually asking society to redetermine an issue that has no bearing on the basic justice of his incarceration.

(Emphasis added; citations omitted.)

Whether the innocent-man view of habeas corpus comports with the historical role of the writ has been the subject of controversy. See, e.g., Hart, The Supreme Court, 1958 Term, Foreword: The Time Chart of the Justices, 73 Harv. L. Rev. 84, 103-04 (1959); Oaks, Legal History in the High Court-Habeas Corpus, 64 MrCH. L. Rev. 451 (1966).

168 This assumes that the federal courts would perceive and respond to the problem more quickly than Congress, which could always reinstate habeas review for procedurally defaulted claims. 
preserve the federal interest in protecting federal constitutional rights from procedural default, the courts may place greater emphasis on the sixth amendment. Such emphasis may create more problems than it would solve.

\section{B. The Problems with Using the Ineffectiveness Doctrine to Preserve Constitutional Rights}

The Supreme Court has failed to give content to the sixth amendment's requirement of effective assistance of counsel; ${ }^{160}$ reliance on sixth amendment doctrine to safeguard constitutional rights in the absence of effective habeas review would be uneven without Supreme Court guidance. Using that doctrine in place of habeas review for procedurally defaulted claims also could damage the attorney-client relationship; the attorney would enter every professional relationship knowing that any procedural default could result in a claim of ineffectiveness. ${ }^{170}$ Further, creating constitutional doctrine to protect constitutional claims from default would hamper experimentation with novel approaches to delivering legal services. ${ }^{171}$

Doctrinal problems aside, federal courts could use ineffectiveness findings to protect constitutional rights from procedural default in two ways. Each is less desirable than the habeas tool.

\section{The Shell Game}

Courts could say that counsel had provided ineffective assistance whenever they default a valid constitutional claim. The

169 See Maryland v. Marzullo, 435 U.S. 1011, 1011-12 (1979) (White, J., dissenting from denial of certiorari and accusing the Court of failing in its "responsibility to determine what level of competence satisfies the constitutional imperative."); Strazzella, supra note 64 , at 484 .

Commentators have not been as quiet. See, e.g., Bazelon, The Defective Assistance of Counsel, 42 U. CiN. L. Rev. I (1973); Bines, Remedying Ineffective Representation in Criminal Cases: Departures from Habeas Corpus, 59 VA. L. Rev. 927 (1973); Finer, Ineffective Assistance of Counsel, 58 ConNex工 L. REv. 1077 (1973); Stone, Ineffective Assistance of Counsel and Post-Conviction Relief in Criminal Cases: Changing Standards and Practical Consequences, Couum. Hum. RTs. L. REv. 427 (1975); Waltz, Inadequacy of Trial Defense Representation as a Ground for Post-Conviction Relief in Criminal Cases, 59 Nw. U.L. Rev. 289 (1964); Note, Indigents' Dissatisfaction with Assigned Counsel, 22 Cuev. ST. L. Rev. 157 (1973); Comment, Incompetency of Counsel, 25 BAyLor L. Rev. 299 (1973); Note, supra note 52.

170 See Tague, supra note 10 , at 66.

171 The Virginia note, supra note 152, points to two further weaknesses in the use of the sixth amendment claim: "First, it may be unduly harsh on defendants whose cases are prejudiced by attorney error that falls short of being constitutionally deficient." Second, "requiring a defendant to prove full ineffective assistance of 
effect of such an approach is the same on both prisoners and states as use of the habeas tool: whenever a prisoner's valid constitutional claim had been defaulted, the prisoner would receive a new trial. Because the state's finality interest would be affected by procedural defaults of valid constitutional claims, the state would attempt to decrease procedural defaults through the various mechanisms under its control. ${ }^{\mathbf{1 7 2}}$ The effect on the state would thus be similar to allowing habeas review of all unintentional procedural defaults. This approach is inferior to use of direct habeas review, however, because it would increase strain on the attorney-client relationship..$^{173}$

\section{Selective Ineffectiveness}

Rather than branding as ineffective the assistance of any attorney who defaults a valid constitutional claim, the courts are likely to find that some unintentional defaults do not constitute ineffective assistance of counsel. By so doing, the courts will promote only the finality of state convictions that rest on procedural defaults of certain kinds-the ones that the courts believe even effective counsel could default. This limited increase in state finality comes, however, at the expense of certain state prisoners who must bear the cost of a system that allows the other kinds of procedural defaults. ${ }^{174}$ The costs fall randomly according to attorney conduct.

counsel forces him into the anomalous position of having to prove two constitutional violations in order to receive the remedy for a single violation." Id. 425 .

172 See supra notes $143-48$ and accompanying text.

173 See supra note 170 and accompanying text.

174 See supra notes 166-67 and accompanying text. But some urge that this need not be unfair if habeas review is granted for defaulted claims that are guiltrelated. See cases cited supra note 55 .

One commentator has criticized the guilt-related approach to habeas review as redundant, arguing that the state's interest in incarcerating the guilty is sufficiently high to ensure protection of those rights because of (1) public outrage over an srroneous outcome, (2) the cost of supporting unjustly incarcerated prisoners, and (3) the danger to society of letting the true criminal go free. See Note, Guilt, Innocence, and Federalism in Habeas Corpus, 65 Cornel L. Rev. 1123, 1142-43 (1980). Such a review ignores the actual pressures on the state when a crime is committed. Public outrage runs highest not when the convicted person claims innocence, but when a crime goes unpunished; thus, the state is pressured not to discern the truth-a quality that the pressuring public is not in a good position to evaluate-but to attain conviction. The second factor-the cost of supporting unjustly incarcerated prisoners-would have force only if the state perceived that it costs more to incarcerate innocent persons than guilty ones. Finally, the public's fear that the real criminal remains free to terrorize society is an active force only in the unusual circumstance when the public actually perceives that the person convicted was not guilty. It seems unlikely that most members of the public ever 
The courts could take a selective ineffectiveness approach in three ways. First, they could enunciate a standard, such as reasonableness, ${ }^{175}$ against which procedural defaults would be judged; if the default is unreasonable, then the attorney has provided ineffective assistance. Second, a court could identify "special" rights, default of which would always constitute ineffectiveness; for example, the court could say that default of a valid fourth amendment claim always constitutes ineffectiveness in a case in which the prosecution introduces the fruits of a warrantless search. Third, the courts could protect constitutional rights against default by requiring the states to employ certain of the tools at the state's command to decrease the incidence of procedural defaults.

Each of the approaches is inferior to allowing habeas review of unintentionally defaulted claims. Using a "reasonableness" standard (or its equivalent) defines ineffectiveness in terms of normal attorney conduct with respect to procedural defaults. By defining ineffectiveness in such terms, the courts do not encourage the states to decrease procedural bypasses-and thus the standard may be eroded by the decreasing competence of area counsel. The standard is thus subject to variations that could result in shifting standards of justice for petitioners.

Additionally, the reasonableness approach removes the state's incentive to decrease defaults not deemed to constitute ineffectiveness. By disallowing review for errors committed by attorney conduct that was "reasonable," a reasonableness rule would discourage the state from using its own tools to increase finality. ${ }^{176}$ In effect, the federal courts have done the state's work for it. The states could ignore defaults in public defenders offices, for example, and combine increased workloads ${ }^{177}$ with draconian sanctions ${ }^{178}$

become sufficiently familiar with the entire case against an accused to make a knowledgable judgment of guilt or innocence. That the accused has been publicly accused probably creates a heavy presumption of guilt in the public's mind, especially when the accused has a prior record. For a more persuasive argument against expansion of the guilt-related approach to habeas review, see Schulhofer, Confessions and the Court (Book Review), 79 Mrcr. L. REv. 865, 888-91 (1981) (reviewing Y. Kamisar, Police InTERrogation and Confessions: Essays IN LAW AND PoLICY (1980)) (expansion of Stone v. Powell approach in context of confessions would not increase efficiency of judiciary).

175 This should not be confused with the position taken by the Virginia note, supra note 152. That note suggests that the Sykes "cause" requirement be considered satisfied whenever an attorney's default is unreasonable. See supra note 152 and accompanying text. Selective ineffectiveness has no relation to "cause"it operates under the sixth amendment.

176 See supra notes 127-42 and accompanying text.

177 See supra note 129 and accompanying text.

178 See supra note 142 and accompanying text. 
for committing reviewable procedural defaults, effectively determining those areas on which the attorney will concentrate. As long as the resulting errors were reasonable, the state has lost no finality-habeas review will be denied-and the state has no incentives to decrease procedural defaults.

The second selective approach is likewise flawed. Singling out "special" rights, the default of which may trigger an ineffectiveness claim, also discourages the state from using the means available to it to decrease certain procedural defaults. The state simply will rely on federal courts to deny claims not involving these "special" rights. Further, because of the state's economic incentive not to discourage unreviewable procedural defaults, more of these defaults may occur, and the federal courts could find themselves in the anomalous position of paying the least attention to those claims most likely to be defaulted. If the state is better able to control public rather than private attorneys, more unreviewable defaults may occur in the state-run system, widening the gap between the quality of legal services accorded the poor and the rich.

The third way for the federal courts to institute a selective ineffectiveness approach, requiring states to use administrative tools to decrease defaults, ${ }^{179}$ like the other two approaches, encourages states to increase procedural defaults of certain, unreviewable claims. ${ }^{180}$ Because compliance with the federal courts' requirements would insulate defaults from review, a state need not use any other tool at its disposal to decrease defaults. Those defaults not under federal protection would go unremedied.

Besides damaging the attorney-client relationship-a fault common to all versions of ineffectiveness doctrine ${ }^{181}$-the third approach is also flawed because it would place the burden of improving legal delivery systems on the federal courts. Because those courts arguably are in a worse position than the states to analyze the costs and benefits of potential reforms to the delivery system, ${ }^{182}$ federally mandated legal delivery systems are more likely to be inefficient than are those that states would adopt if all uninten-

170 This approach does avoid one problem plaguing the reasonableness standard approach: it does not involve standards that define ineffectiveness in terms of normal attorney conduct. The state, therefore, having no hope of altering the standard, also has no incentive to increase procedural defaults in general:

180 See supra text accompanying notes 177-78.

181 See supra note 170 and accompanying text.

182 See supra notes $143-48$ and accompanying text. 
tionally bypassed claims were cognizable on habeas. Because the court-mandated legal innovations would be based on sixth amendment constitutional doctrine, federal courts would be less able to take a trial-and-error approach to legal reform than would the states. Furthermore, extensive inquiry by federal courts into the states' legal delivery systems would heighten state-federal friction. ${ }^{183}$

\section{The Superiority of Defining "Cause" to Include All Unintentional Defaults}

Although Wainwright $v$. Sykes has been highly criticized, it is the current law of the land. The opinion, though often perceived as harsh, does express legitimate concerns-namely, curbing deliberate use of habeas corpus to bypass the state courts and promoting the state's right to protect its system of orderly administration.

To work within the Sykes framework, therefore, is to properly balance the finality and administrative concerns against the concerns that defendants get a fair trial with competent attorneys, that procedural defaults are minimized, and that defendants' constitutional claims are thus protected. Allowing habeas review of all unintentionally defaulted claims provides the best solution to this balancing problem.

The state's concern that its procedural rules not be deliberately flouted will be safeguarded because a deliberate default, of course, would not be unintentional, and therefore would be unreviewable. As to these claims, finality is assured, as is orderly state procedure.

Allowing habeas review of unintentionally defaulted claims differs from the deliberate bypass test of Fay $v$. Noia ${ }^{184}$ in two important respects. First, under the test proposed here the petitioner must show prejudice arising from the procedural default. Second, the petitioner would be required to prove the default was not deliberate to obtain review. Placing the burden of proving cause on the petitioner comports with the American Bar Association's recommendation that attorneys fully discuss strategy with

183 See Cover \& Aleinikoff, Dialectical Federalism: Habeas Corpus and the Court, 86 YALE L.J. 1035, 1083 (1977) (although cutbacks in habeas jurisdiction might initially decrease state-federal friction, subsequent use of the sixth amendment to promote federal aims could cause state-federal friction to return "with a vengeance."). 
their clients. ${ }^{185}$ More importantly, and in contrast with Noia, ${ }^{186}$ the state clearly would not have the burden of proving deliberate by-pass and thus would not be strapped by an inadequate record or by the passage of time.

The state is in the best position to ensure that attorneys discuss potential claims with their clients, just as it is in the best position to prevent procedural defaults from occurring. A system allowing habeas review for unintentionally defaulted claims will give the state an economic incentive-the loss of finality, and the costs incurred from habeas review-to use its tools to decrease procedural defaults. The federal courts thus can let the states decide how best to ensure competent trial systems, and need not interfere if the states are successful.

Finally, allowing habeas review of unintentionally defaulted claims is superior to reliance on sixth amendment ineffectiveassistance-of-counsel claims. Habeas review for unintentional defaults is less of a direct attack on the attorney; the attorney-client relationship is therefore less vulnerable. No variable standard, such as reasonableness, can be eroded because all unintentional defaults, whether reasonable or not, can be reviewed. The state's incentive to decrease procedural defaults remains intact, and the federal courts are not in the position of imposing their own ideas of effective legal delivery systems on the states.

\section{Conclusion}

The failure of the federal courts of appeals to develop a coherent approach to the availability of habeas review of unintentionally defaulted claims can be traced to the Supreme Court's inaccurate assumption in Wainwright $v$. Sykes ${ }^{187}$ that attorneys almost always act deliberately. Because that assumption has prevented the courts from perceiving why procedural defaults actually

185 See ABA STANDARDs, supra note $41, \$ \$ 5.1$, at $234-35,5.2$, at $237-38$ ("[T] $\mathrm{T}$ he lawyer should advise the accused with complete candor concerning all aspects of the case, including his candid estimate of the probable outcome.") $(\$ 5.2(\mathrm{~b})$ states that although certain decisions are the attorney's, they should be made "after consultation with his client." Id. 238). Chief Justice Burger has suggested that the spur-of-the-moment nature of criminal trials makes it impossible for attorneys to consult with clients before making trial decisions. See Wainwright $v$. Sykes, 433 U.S. at 93 (Burger, C.J., concurring). But proper preparation of a case should enable an attorney to anticipate nearly any constitutional claim that might arise and to consult with a client before trial in the unlikely event that the attorney thinks that the client's case would be furthered by failing to raise the claim. See supre notes 86-98 and accompanying text.

186 See supra note 22.

187433 U.S. 72 (1977). 
occur, the courts have not considered the extent to which states can control the incidence of procedural default. Analysis of the ways states behave when unintentional defaults are directly cognizable, as well as the consequences of denying habeas review for any or all unintentionally defaulted claims, suggests that the federal courts should define "cause" under Sykes such that all unintentionally defaulted claims will be directly cognizable on habeas. By promoting efficient means for delivery of legal services, such an approach best balances the state's interest in finality and the federal government's interest in protecting constitutional claims from unintentional procedural default. 